\title{
Corrigendum
}

Learning \& Memory 25: 550-563 (2018)

Corrigendum: Sign-tracking is an expectancy-mediated behavior that relies on prediction error mechanisms

Rifka C. Derman, Kevin Schneider, Shaina Juarez, and Andrew R. Delamater

In Figure $1 \mathrm{~B}$ of the above-mentioned article, the symbols in the crossing lines of the subpanel entitled "intermediate" had been inadvertently reversed. The figure has now been corrected in the article online.

doi: $10.1101 / \operatorname{lm} .049783 .119$ 


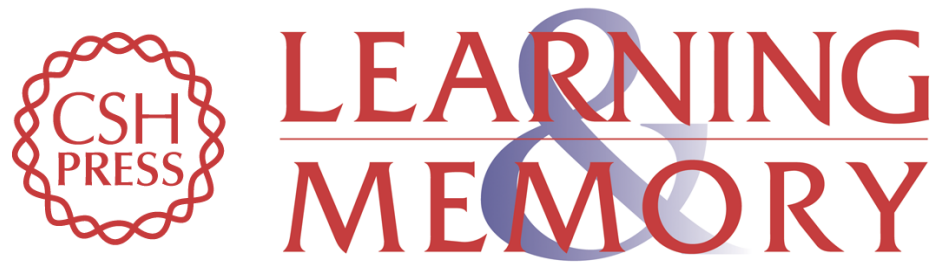

\section{Corrigendum: Sign-tracking is an expectancy-mediated behavior that relies on prediction error mechanisms}

Rifka C. Derman, Kevin Schneider, Shaina Juarez, et al.

Learn. Mem. 2019, 26:

Access the most recent version at doi:10.1101//m.049783.119

Related Content Sign-tracking is an expectancy-mediated behavior that relies on prediction error mechanisms

Rifka C. Derman, Kevin Schneider, Shaina Juarez, et al.

Learn. Mem. October , 2018 25: 550-563

\section{License}

Email Alerting Receive free email alerts when new articles cite this article - sign up in the box at the Service top right corner of the article or click here. 